\title{
Strategies of Utilising Agriculture Wastewater for Microalgae Cultivation and Its Possible Applications: A Review
}

\author{
Jannatulhawa Jasni ${ }^{1,2^{*}}$, Nazlina Haiza Mohd Yasin33, Noraini Ruslan4, Che Nurul Ashikin Che Mat Noor3, Shalini Narayanan \\ Arisht $^{1,2}$, Harizah Bajunaid Hariz ${ }^{1,2}$, Mohd Sobri Takriff ${ }^{1,5}$ and Mohd Shaiful Sajab ${ }^{1}$ \\ ${ }^{1}$ Department of Chemical and Process Engineering, Faculty of Engineering, Universiti Kebangsaan Malaysia, 43600 \\ Bangi Selangor, Malaysia \\ ${ }^{2}$ UKM-YSD Chair for Sustainability, Faculty of Engineering, Universiti Kebangsaan Malaysia \\ ${ }^{3}$ Department of Biological Sciences and Biotechnology, Faculty of Science and Technology, Universiti Kebangsaan
}

Malaysia, 43600 Bangi Selangor, Malaysia

${ }^{4}$ Department of Technology and Natural Resources, Faculty of Applied Science and Technology, Universiti Tun Hussein

Onn Malaysia, Malaysia

${ }^{5}$ Chemical \& Water Desalination Engineering Program, College of Engineering, University of Sharjah, UAE

\begin{abstract}
Microalgae have been found to have high prospects in wastewater treatment, particularly from agriculture. However, the uneconomical algal medium growth has become the major disadvantaged in algal industry. Multiple attempts includes the development of microalgae phycoremediation technology has been integrated into wastewater treatment to reduce the cost of expensive wastewater remediation. Utilising wastewater as a low-cost nutrient medium offers a synergistic effect of wastewater nutrient removal and co-production of valuable biomass simultaneously. This paper is mainly focused on potential, ability, strategy, application (i.e., palm oil wastewater), limitation and challenges of microalgae in agricultural wastewater treatment using phycoremediation. The understanding of cultivating microalgae using agriculture wastewater shall promote the utilisation of wastewater more sustainably in the future. The possible solutions in the application of microalgae for aquaculture and agriculture sector is also discussed in this review. Overall, the utilisation of wastewater in media cultivation for microalgae is restricted due to the expensive treatment and safety concern. However, this pitfall can be reduced in the future together with a further intensive scientific study, advanced technology, better management system and applying better standard protocol.
\end{abstract}

Keywords: pre-treatment; agri-aquaculture integrated system; phycoremediation; metabolites

\section{INTRODUCTION}

The global threat of depleted natural resources for fuels, foods and energy has made human desperately seek for sustainable and renewable resources. Nowadays, microalgae which offer exciting industrial potential in economic activities are being explored globally. Generally, microalgae utilised sunlight as an energy source, inorganic nutrients and inorganic carbon to generate biomass through photosynthesis. The biomass could potentially be used as feedstock for bioenergy, biofertilisers, pharmaceutical, animal, protein alternative for fish and poultry feed, and other value-added products (Priyadarshani \& Rath, 2012; Ansari et al., 2017). The wide range of compounds derived from microalgae metabolic pathways offers in-demand compounds like fatty acids, steroids, carotenoids, polysaccharides, lectins, mycosporine-like amino acids, 
halogenated compounds, polyketides and toxins (Sathasivam et al., 2017).

Approximately, 50,000 of microalgae are living on earth and capable of producing novel compounds for many purposes, and only a few were used practically for the commercial purpose (Bharathiraja et al., 2015). The desirable attributes of microalgae as listed in Table 1 make microalgae a superior microorganism for multitude applications. The ongoing research on utilising microalgae as a new renewable resource is crucial in this era. Producing commercial microalgae in an abundant quantity is a major problem due to its high operational cost, approximately US70 for every litre of biomass produced (Mehmod et al., 2014). In order to reduce the production cost, this process can be coupled with wastewater effluent treatment for high-value products and biomass production. Agro-based industries (i.e. POME, piggery wastewater, dairy wastewater, paddy-soaked rice mill wastewater) are well established in Malaysia. Therefore, the wastewater generated from these agro-based industries could be utilised as microalgae cultivation media.

However, the microalgae biomass cultivated in wastewater treatment system has safety concern due to the high content of microorganism, COD, BOD, turbidity and suspended solids. Therefore, this paper discussed the appropriate pretreatments process through mechanical, chemical or biological means (i.e., electrochemical oxidation, coagulation, fungal pre-treatment, autoclave, ultraviolet ray, filtration and dilution) before being processed for human and animal consumption. Microalgae are important bioremediation agent in agricultural wastewater. Agricultural wastewaters have an abundance supply of N, P, K originated from fertiliser application (Vassilev \& Vassileva 2016). Microalgae can assimilate a large amount of nitrogen, phosphate and carbon for their growth and turn into biomass containing lipids, carbohydrates and proteins. It is a win-win situation where microalgae can utilise the nutrients from wastewater that is always a limiting factor for microalgae growth. Studies have been reported, some microalgae species (e.g., Botryococcus, Chlamydomonas, Phormidium, Spirulina) has promising efficacy in wastewater treatment (Chinnasamy et. al., 2010; Stephens et al., 2010).

This review focus on the recent trends of using tropical agriculture wastewater to culture microalgae and the co- production of valuable biomass is utilised into multiple applications, especially in agriculture and aquaculture applications. The approaches in wastewater pre-treatment and ways to increase the biomass yield are presented in this paper to make the wastewater as a possible source of nutrients for microalgae cultivation. In addition, the integration of applying microalgae into aquaculture and agriculture system with improved knowledge and technology will benefit many, especially the rural livelihood. Overall, the understanding of cultivating microalgae using agriculture wastewater shall promote the utilisation of wastewater more sustainably in the future.

\section{A. The Characteristic of Microalgae}

Microalgae are simple organisms with a cellular structure which can be found in almost all parts of the world, varied in sizes and structures and are classified mainly based on their pigmentations (Demirbas, 2010; Takriff et al., 2016). Microalgae size are $<400 \mu \mathrm{m}$ and generally of $1-30 \mu \mathrm{m}$ in diameter (Demirbas, 2010; Ullah et al., 2015). According to Rathod (2015), the basic elements of microalgae are carbon, hydrogen, oxygen, nitrogen and phosphorus with the stoichiometric formula of $\mathrm{C}_{106} \mathrm{H}_{181} \mathrm{O}_{45} \mathrm{~N}_{16} \mathrm{P}$. Their morphological features are round, oval, cylindrical, fusiform cells, projection-like thorn and cilia (Drew et al., 2013).

The classification of algae is complex and controversial yet can be classified into prokaryotic or eukaryotic. The organelles (nucleus, chloroplast, mitochondria, Golgi body, flagella and plasmalemma) of eukaryotic microalgae are membrane-bounded while the organelles in the prokaryotic microalgae are lack of membrane-bounded (Achyuthan et al., 2017). The major taxonomical classification of algae includes Rhodophyta (red algae), Chlorophyta (green algae), Phaeophyta (brown algae), Bacillariophyta (diatoms), Chrysophyta (golden algae), Haptopyta, Stramenopiles and Dynophyta (Heimann \& Huerlimann 2015; Udaiyappan et al., 2017). The largest group of microalgae on earth is believed from the group of diatom (Demirbas, 2011).

Genetically distinct physiological and biochemical characteristics assisted in manufacturing a variety of unique bioactive compounds (Priyadarshani \& Rath 2012). It contributed $50 \%$ to the primary productivity of the aquatic ecosystem, which assimilates sunlight, water and carbon 
dioxide into biomass (Field, 1998; Mehmood et al., 2014) The growth of algae depends very much on its physical parameter; light intensity, $\mathrm{pH}$, turbulence, salinity, temperature, quality and quantity of nutrients.

Table 1. Major advantages and disadvantages of microalgae using microalgae as feedstock (Plaza et. al., 2010; Vassilev \& Vassileva, 2016)

\begin{tabular}{|c|c|}
\hline Advantages & Disadvantages \\
\hline $\begin{array}{l}\text { Sustainable and renewable } \\
\text { resources }\end{array}$ & $\begin{array}{l}\text { May encounters fluctuation } \\
\text { in algae feedstock supply } \\
\text { due regional and seasonal } \\
\text { availability. }\end{array}$ \\
\hline $\begin{array}{l}\text { Do not compete with } \\
\text { human and animal feeds } \\
\text { and foods }\end{array}$ & $\begin{array}{l}\text { Requires high production } \\
\text { costs for pre-treatment, } \\
\text { cultivation, harvesting, } \\
\text { transportation and storage. }\end{array}$ \\
\hline Able to sequester $\mathrm{CO}_{2}$ & $\begin{array}{l}\text { Causing other } \\
\text { environmental problems }\end{array}$ \\
\hline $\begin{array}{l}\text { Able to improve standard } \\
\text { of living in rural } \\
\text { communities }\end{array}$ & $\begin{array}{l}\text { Disturb the balance of } \\
\text { natural ecosystems }\end{array}$ \\
\hline High productivity & $\begin{array}{l}\text { Neurotoxic properties of } \\
\text { certain algae can cause } \\
\text { serious health problem. }\end{array}$ \\
\hline $\begin{array}{l}\text { Highly biodegradable \& } \\
\text { suitable for bioremediation } \\
\text { Harvestable within short } \\
\text { period of time }\end{array}$ & $\begin{array}{l}\text { Genetically modified algae } \\
\text { used in the cultivation can } \\
\text { disturb the well-being of } \\
\text { natural algae. }\end{array}$ \\
\hline
\end{tabular}

\section{APPLICATION OF MICROALGAE FOR WASTEWATER REMEDIATION}

Microalgae are widely used in wastewater treatment due to its ability to removes contaminants and the biomass produced is considered sustainable, although some disadvantages and advantages were found (Table 1). Nitrogen, phosphorus and carbon are the three main pollutants found in wastewater (Delrue et al., 2010). Primary and secondary treatment for wastewater often causes eutrophication and other environmental problems when discharged into the environment (Rathod, 2015). To some extends, it only removes organic materials but fails to eliminate inorganic materials like nitrogen, phosphorus and several heavy metals (Rathod, 2015).
The wastewater is better choice due to containing some nutrition such as $\mathrm{N}$ and $\mathrm{P}$, which were essential elements for microalgal cell growth. Nitrogen is a major nutrient for microalgae production, but it is normally supplied as nitrate in concentration of $50 \mathrm{mgN} / \mathrm{L}$ (Fernandez et al., 2018). Phosphorous is the other major nutrient required for microalgae production. In effluents, phosphorous is normally found as phosphate or in organic compounds. The wastewater usually has high chemical oxygen demand (COD) and BOD due to the presence of organic components (sugars, soluble starch, ethanol, volatile fatty acids).

The efficiency and ability of microalgae in treating mineral pollution (i.e., ammonium, nitrate, phosphate) have been well documented (Delrue et al., 2016). A study reported, treatment with Chlorella sp. has reduced chemical oxygen demand (COD) by 70\%, total nitrogen by $61 \%$ and total phosphorus by 61\% (Min et al., 2011). Choi and Lee (2012) found that the increasing abundance of Chorella vulgaris from $1-10 \mathrm{~g} / \mathrm{L}$ during wastewater treatment increase the removal of biochemical oxygen demand (BOD) (80\% - 83\%), COD $(78 \%$ - 82\%), total nitrogen $(81 \%-85 \%)$ and total phosphorus (32\% - 36\%). Metabolically, microalgae grow in the presence of carbon dioxide $\left(\mathrm{CO}_{2}\right)$ and light through photosynthesis process thus in wastewater, it can consume bicarbonate ions or $\mathrm{CO}_{2}$ for carbon source and obtaining inorganic nutrients (e.g., nitrogen and phosphorus) for growth.

Microalgae are able to capture carbon dioxide from the air 50 times higher than terrestrial plants and produce very high biomass (Min et al., 2011). It can reduce the carbon content in the air by capturing 1.6 to 2.0 tonnes of $\mathrm{CO}_{2}$ for every 1 ton of algal biomass produced, thus reducing the GHG emission (Abinandan \& Shanthakumar, 2015; Vassilev \& Vassileva, 2016). Microalgae are among superior organism in wastewater treatments process. However, their efficiencies are depending on the composition of the wastewater, and the result may vary due to its species-dependent nature, as shown in Table 2. Their capabilities are depending on the form of the wastewater and vary according to the microalgae species (i.e., Botryococcus, Chlorella and Scenedesmus can assimilate a large amount of $\mathrm{CO}_{2}$ ) (Andreotti et. al., 2017; Apandi et al., 2018). 


\section{A. Challenges of Using Wastewater as Media for Biomass Production}

The utilisation of wastewater as a media for microalgae culture is desirable as it can provide nutrients and reducing the operation cost at least 50\% (Lardon et. al., 2009; Xin et. al., 2010; Dalrymple et al., 2013). However, different microalgae species have different efficiencies towards wastewater treatment and can be intoxicating if not reduced to the acceptable level (Kumar \& Goyal, 2010; Abinandan \& Shanthakumar, 2015).

Wastewater contain a significant amount of suspended solids that may interfere with the growth process of the microalgae. The internal shading increased turbidity and limits the photosynthetic activity of microalgae (Larsdotter, 2006). Other challenges of using wastewater as media for microalgae cultivation are summarised in Figure 1.

Environmental threat and health problems: High nutrient content in wastewater media such as nitrate, phosphate and some macronutrients can limit the light penetration for mass-cultivation (Cho et al., 2011). It also possesses various environmental threat (i.e., water contamination, offensive smell and potentially harmful emission to the environment) (Plaza et al., 2010). Besides, wastewater contains numerous toxic substances that can impede the growth of microalgae and bioaccumulate in human's body if being consumed (Kumar \& Royal, 2010).

Nutrient safety: At commercial scale, the end products need to be produced in a massive scale operation. Thus, it is vital to make sure the products are safe to be consumed when utilising wastewater as a nutrient to cultivate microalgae. It is essential to ensure their organic contents as they can be toxic if consumed (Safafar et al., 2016). This is due to the possibility of microalgae to absorb either low essential nutrients or unwanted and alarming substance that lead to low yield and lack quality of biomass (Khatoon et. al., 2016; Ravindran et al., 2016). The best way is always to dilute the wastewater before being used for microalgae cultivation (Chiu et. al., 2014; Ravindran et al., 2016). Wastewater should be diluted to a tolerable limit where the selected strain could grow efficiently in wastewater.

Table 2. Summary of research done by the various researchers utilising tropical agriculture wastewater using various microalgae species for wastewater treatment

\begin{tabular}{|c|c|c|c|}
\hline Microorganism & $\begin{array}{l}\text { Tropical } \\
\text { agriculture } \\
\text { Wastewater }\end{array}$ & Finding and remarks & References \\
\hline $\begin{array}{l}\text { Scenedesmus sp. and } \\
\text { Chlorella } \mathrm{sp} .\end{array}$ & $\begin{array}{l}\text { Palm oil mill } \\
\text { effluent (POME) }\end{array}$ & $\begin{array}{l}\text { Nutrient removal of } 86 \% \text { Total Nitrogen } \\
\left.\text { (TN), 85\% Reactive Phosphate ( } \mathrm{PO}_{4}^{-3}\right) \text {, } \\
77 \% \text { Total Organic Carbon (TOC) and } 48 \% \\
\text { Chemical Oxygen Demand (COD) }\end{array}$ & $\begin{array}{l}\text { Hariz et al. } \\
\quad(2019)\end{array}$ \\
\hline $\begin{array}{l}\text { C. vulgaris, } C . \\
\text { pyrenoidosa, } \\
\text { Haematococus pluvialis, } \\
\text { S. obliquus, S. platensis } \\
\text { and Porphyridium } \\
\text { cruentum }\end{array}$ & Piggery wastewater & $\begin{array}{l}\text { Nutrient removal of } 89.5 \% \mathrm{TN} \text { and } 85.3 \% \\
\mathrm{TP}\end{array}$ & $\begin{array}{l}\text { Wang et al. } \\
\text { (2016a) }\end{array}$ \\
\hline Mixed microalgae & Dairy Wastewater & $\begin{array}{l}\text { Removal of } 90 \% \text { organic carbon, } \\
\text { biochemical composition of } 38 \% \\
\text { carbohydrates, } 15 \% \text { proteins and } 22 \% \\
\text { lipids }\end{array}$ & $\begin{array}{l}\text { Hemalatha et } \\
\text { al. (2019) }\end{array}$ \\
\hline Scenedesmus obliquus & $\begin{array}{l}\text { Paddy-soaked rice } \\
\text { mill wastewater }\end{array}$ & $\begin{array}{l}\text { Removal of } 96 \% \text { ammonical nitrogen, } \\
97.58 \% \text { phosphates, biochemical } \\
\text { composition of lipids } 12 \% \text {, protein } 40 \% \text {, } \\
\text { and carbohydrates } 20 \%\end{array}$ & $\begin{array}{l}\text { Umamaheswari } \\
\text { \& } \\
\text { Shanthakumar } \\
\text { (2019) }\end{array}$ \\
\hline
\end{tabular}




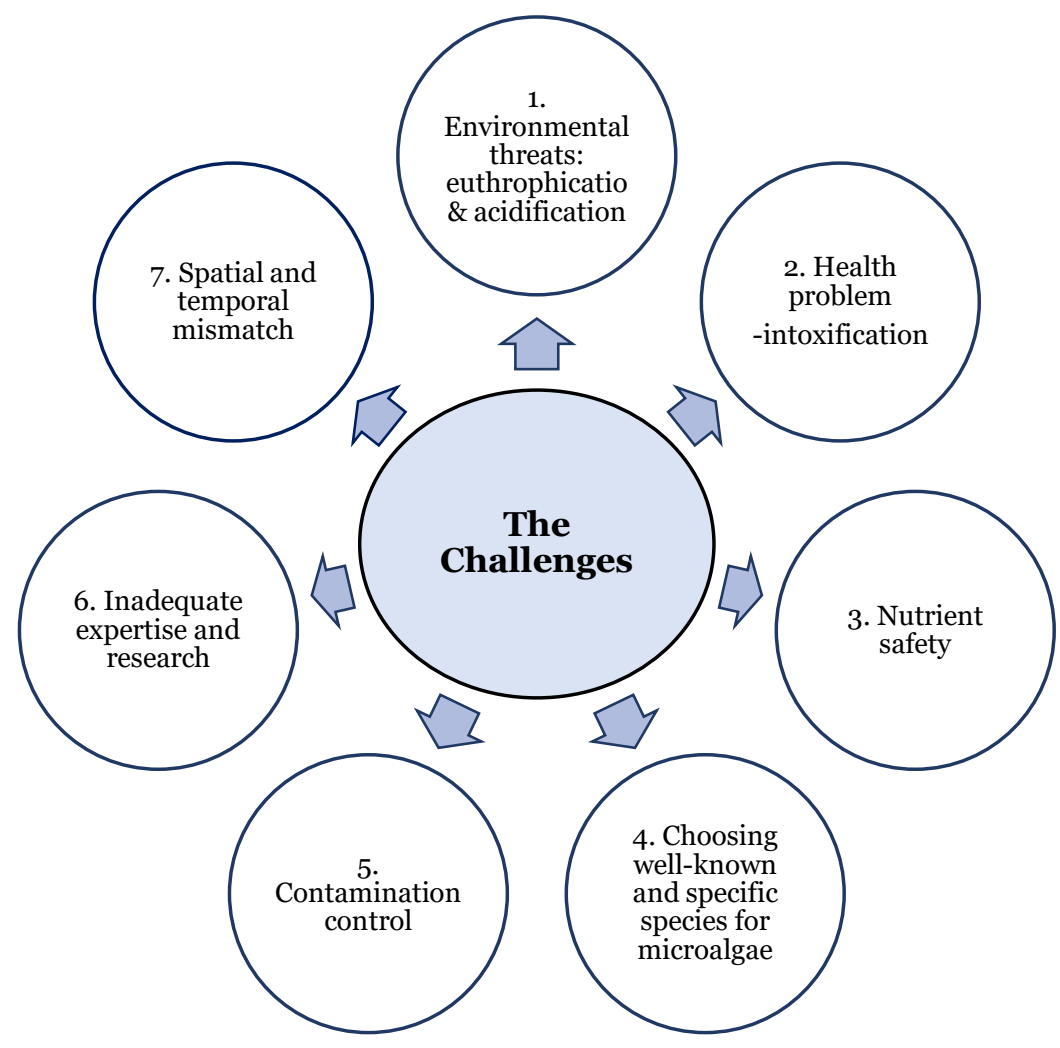

Figure 1. Challenges of using wastewater as media for microalgae (Plaza et. al., 2010; Ndukwe et. al., 2012; Wu et. al., 2014; Muylaert et. al., 2015; Delrue et. al., 2016; Safafar et. al., 2016; Maizatul et al., 2017).

Choosing well-known and specific species of microalgae: The potential use of microalgae in wastewater treatment has been evaluated through the ability of species in treating specific pollutants (i.e., ammoniacal nitrogen, phosphorus) and wastewater (i.e., industrial, agriculture) (Delrue et al., 2016). Not all microalgae species meet a specific nutritional requirement to serve their purpose. Excellent compatibility between microalgae species with the specific properties of wastewater is required to ensure the successfulness of the treatment. Thus, a preliminary screening technique is crucial to choose the suitable target species depending on their growth tolerance on the wastewater environment. Prior to that matter, there must be proper knowledge about the specific characteristics and biochemical composition of microalgae (Brown, 2002). For a commercial purpose, it is advisable to choose native microalgae species that well adapted to their environment as each product from microalgae usually distinct and species dependent (Maizatul et al., 2017).

Contamination control: The occurrence of biocontamination in microalgae cultivation tank is high when using wastewater (Wu et al., 2014). For a small scale, the sterilisation method is proven useful to prevent contamination. However, the sterilisation method is not suitable to be used in large-scale cultivation. The best options are to screen and choose the strongest resistance microalgae and apply control technology to manipulate the genetic of microalgae against contamination (Chinnasamy et. al., 2010; Wu et. al., 2014; Gani et al., 2016).

Inadequacy expertise and research: Although there are many scientific studies that were conducted to utilise wastewater for microalgae cultivation; there is still a gap for some relevant information. There have been minimal detailed investigations on other applications that include the efficacy and safety of consuming it. In recent years, there have been experiments and trials but only on a small scale (Ndukwe et. al., 2012; Maizatul et al., 2017). Researchers have not treated this subject in much detail, which contributes to a limited number of relevant expertise in this area. The knowledge from expertise is very critical to ensure the success in commercial applications.

Wastewater and microalgae availability: Microalgae farm often located far from the wastewater sources and it is not an economical wise to transport over a long distance. It 
is recommended to operate the microalgae farm near wastewater sources as the cost of transportation can be a major burden to the manufacturer. Another possible problem that may arise in an urban area is the limitation of space and high land rental cost. The spatial and temporal mismatch of microalgae between microalgae and wastewater availability makes the microalgae business look unattractive according to Muylaert et al. (2015). Despite all the above mention challenges of using wastewater to grow microalgae, some strategies can be applied to make it feasible as culture media (i.e., pretreatment).

\section{WASTEWATER TREATMENT}

Wastewater must undergo several pretreatment processes before being feasibly used as culturing media for microalgae, including various methods of mechanical, chemical or biological. Majority of microalgae species can accumulate heavy metals concentration level about $8 \%$ of their dry mass (Mehmood et al., 2014). Basic wastewater treatment of raw sewage includes pretreatment, primary treatment, secondary treatment and tertiary treatment before being released into receiving bodies. As stated by regulatory agencies, industrial wastewaters must be pretreated before being discharged to the municipal sewer system to remove materials (i.e., silver ions which are toxic to bacteria) that inhibit the biological processes in secondary treatment. Pretreatment also important to reduce operational problems.

The pretreatment processes aim to lower microorganism, COD, BOD, turbidity and suspended solids in the wastewater treatment system. However, the efficacy of these processes is hindered with the occurrence of numerous inhibitory substances such as complex organics, heavy metal substances and extracellular polymeric substances (EPS) (Carballa et. al., 2011; Abelleira-Pereira et al., 2015). Examples of pretreatment methods used to treat wastewater are tabulated in Table 3. Pretreatment has proven to remove high unwanted nutrients (i.e., COD, BOD, TN and TP) and improved productivity.

Pre-treatment can improve microalgae cultivation process, but some method like Fenton and visible-photocatalysis pretreatment method requires high energy demand, thus increasing the operational cost and uneconomical for field application. Therefore, it is advisable to choose the right wastewater pre-treatment to minimise the shortcoming effects before the cultivation and slight modification can reduce the energy demand. Overall, any pre-treatment process of wastewater is highly recommended to enhance microalgal growth and production of various products (i.e., cosmetic, pharmaceutical). 
Table 3. Recent pretreatment methods used to treat wastewater

\begin{tabular}{|c|c|c|c|}
\hline Wastewater type & Pretreatment & Contaminant removal and productivity & References \\
\hline Yard waste wastewater & Electrochemical & net energy gain of $4.75 \mathrm{~kJ} / \mathrm{g}$, biogas production improved $55.4 \%$ & Panigrahi \& Dubey (2019) \\
\hline Sewage sludge wastewater & Microwave & $\begin{array}{l}\text { OLR up to } 2.80 \times 10^{-5} \mathrm{~kg} \text { TVS, increased the methane yield by } 20 \%, 70 \% \\
\text { biodegradability }\end{array}$ & Gil et al. (2018) \\
\hline Furfural wastewater & Acid & Increased $59 \%$ of methane production & Wang et al. (2019) \\
\hline Folic acid (FA) wastewater & $\begin{array}{l}\text { Three-dimensional } \\
\text { electro-Fenton }\end{array}$ & COD removal $43.5 \%$ and $\mathrm{TN}$ removal $70.4 \%$ in $6 \mathrm{~h}$ & Zheng et al. (2019) \\
\hline Farm wastewater & $\begin{array}{l}\text { Thermo oxidation and } \\
\text { alkali }\end{array}$ & Yield methane $62 \%$ higher & Xiong et al. (2020) \\
\hline Olive mill wastewater & Ultrasound & $\begin{array}{l}\text { Increased SCOD/TCOD ratio from } 0.59 \text { to } 0.79 \text {, produced approximately } \\
20 \% \text { more biogas and methane }\end{array}$ & Oz \& Uzun (2015) \\
\hline $\begin{array}{l}\text { Palm Oil Mill Effluent } \\
\text { (POME) }\end{array}$ & Fenton oxidation & TOC reduction of $91 \%$ & Gamaralalage et al. (2019) \\
\hline
\end{tabular}




\section{CO-PRODUCTION OF VALUE-ADDED PRODUCT FROM MICROALGAE BIOMASS}

Previously, microalgae grown in wastewater was meant for energy production and limited for other applications. Nowadays, microalgae are grown to accumulate their valueadded products; pigment, carbohydrate, protein and lipid. Table 5 summarises the useful metabolites in different microalgae species that has been used for many applications such as for food, pharmaceutical, cosmetic and fertiliser.

Primary (i.e. carbohydrates, proteins and lipids) and secondary metabolites (i.e. antibiotics, antiviral, antitumor, antioxidant, terpenoids, phlorotannins, steroids, phenolic compounds, and halogenated ketones) in microalgae carry its own functions. Primary metabolites are for growth while secondary metabolites act as a defence mechanism for microalgae. Secondary metabolites are extracted and widely used in pharmaceutical and cosmetics (Prathana and Maruthi 2019).

These metabolites can be induced by manipulating their growth condition. For instance, when microalgae are exposed to a radical stress condition, protective systems are developed against radical stress by preventing the accumulation of free radicals (Udaiyappan et al., 2017). This will help them to protect themselves from cell-damaging activities. The metabolites induced by this stress condition can be extracted and potentially be useful for human well-being.

\section{THE SIGNIFICANT USE OF MICROALGAE BIOMASS CULTIVATED IN WASTEWATER FOR AQUACULTURE FEED}

In a bigger picture, the whole algal biomass cultivated in wastewater is best suited applied for aquaculture feed, biohydrogen and biofertiliser purposes.

\section{A. Aquaculture Feed}

Sources for high-quality nutrition-filled food invariably one of the high demands in the aquaculture sector. Hence, the need for seafood continuously increases, which lead to the increasing value of the aquaculture market and products. Even then, at the early 1990s, most of microalgae species such as Chlorella sp., Chaetoceros sp. and Isochrysis sp. were already utilised as a feed for bivalves, shrimp and fish in juvenile stages (Shamsudin, 1992; Udaiyappan et. al., 2017;
Show et. al., 2017; Cheah et al., 2018). The nutritional compositions that microalgae have to offer such as high level of PUFA, crucial protein and omega- 3 can potentially replace the function of fish meal and oil required in aquaculture feed (Lenihan-Geels et. al., 2013; Roy et. al., 2014; Yaakob et. al., 2014; Khatoon et. al., 2016; Younis et al., 2018).

Since protein is considered the most expensive nutrient in fish feed, it may be crucial to develop sustainable alternatives to fishmeal. Compared to the other protein sources, the protein content in microalgae is higher, even higher than egg, meat and soybean (Table 4).

Table 4. The comparison of protein content from typical composition of commercially available feed Ingredients and microalgae species (Guedes et. al., 2015; Koyande et al., 2019).

\begin{tabular}{cc}
\hline Feed ingredients & $\begin{array}{c}\text { Protein content } \\
\text { (\% dry matter) }\end{array}$ \\
\hline Poultry meal & 58.0 \\
Corn-gluten & 62.0 \\
Soybean & 44.0 \\
Wheat meal & 12.2 \\
Soybean & 44.0 \\
Poultry meal & 58.0 \\
Whole egg & 47 \\
Fish meal & 63 \\
Chlorella sp. & $50-60$ \\
Spirulina sp. & $60-70$
\end{tabular}

It is quite challenging in culturing microalgae in wastewater for aquaculture application because of the disease threat and food security concern. However, one research conducted by Hende et al. (2015) found that the harvested microalgaebacterial flocks from aquaculture wastewater can be used as a partial inclusion in the diet of juvenile Pacific white shrimps Litopenaeus vannamei to enhance the pigmentation of the cooked shrimp tails without affecting the shrimp survival, weight gain, size distribution and food conversion rate. Another study conducted by Loo et al. (2012) found that bacterium Rhodovulum sulfidophilum and microalgae Nannochloropsis sp. cultured in Palm oil mill effluent can be used as a diet for marble goby larvae and has a better result if it is indirectly fed through Artemia nauplii or rotifers up to $35-55 \%$ or $44-49 \%$ of survival at $5 \mathrm{~g} \mathrm{~L}-1$ salinity, respectively. In short, it is proven that the cultivation of 
microalgae using wastewater media is not impossible under controlled conditions to reduce the risk of disease and food security. It is suggested that additional pre- and posttreatment can tackle this problem quickly. Microalgae are versatile and can serve many purposes in the aquaculture sector.

\section{Formulated fish pellet}

The fish pellet is one of the widely used form of feed-in aquaculture, in which microalgae biomass will be incorporated into the pellet according to their specific nutritional requirements to promotes health, colour and growth of targeted aquaculture organisms (Relicardo, 2015). This method is the most preferred method by most aquaculture farmer because of its lower risk of infection by disease carrier.

Table 5. Useful metabolites in microalgae biomass

\begin{tabular}{|c|c|c|c|}
\hline Species & Metabolites & Applications & References \\
\hline \multicolumn{3}{|l|}{ Dunaliella tertiolecta } & Diprat et al. (2017) \\
\hline Arthrospira and Chlorella & Extract & Cosmetic & $\begin{array}{l}\text { Patrick \& Barbara } \\
\qquad(2005)\end{array}$ \\
\hline Characium terrestre, & & UV protectant & Priyadarshani \& Bath \\
\hline $\begin{array}{c}\text { Chlorogloeopsis sp., Chlorella } \\
\text { sorokiniana, Dunaliella } \\
\text { tertiolecta }\end{array}$ & $\begin{array}{l}\text { Scytonemin and } \\
\text { mycosporine-like } \\
\text { amino acid }\end{array}$ & & $(2012)$ \\
\hline Dunaliella salina & Beta-carotene & Food colorant & $\begin{array}{c}\text { Priyadarshani \& Bath } \\
\text { (2012) }\end{array}$ \\
\hline Chlorella vulgaris & Phenolic compounds & $\begin{array}{l}\text { Immune-modulating, } \\
\text { antitumor, antibacterial, } \\
\text { and anti-inflammatory }\end{array}$ & $\begin{array}{l}\text { Kwang et al. (2010) } \\
\text { Safi et al. (2014) }\end{array}$ \\
\hline $\begin{array}{c}\text { Chlorella vulgaris \& Spirulina } \\
\text { platensis }\end{array}$ & Minerals and vitamin & Biofertiliser & $\begin{array}{c}\text { Safi et al. (2014) } \\
\text { Dineshkumar et al. } \\
\text { (2017) }\end{array}$ \\
\hline Tisochrysis lutea \& & - & Inclusion in fish diet & Vizcaíno et al. (2018) \\
\hline \multicolumn{4}{|l|}{ Nannochloropsis gaditana } \\
\hline Cyanothece epiphytica & $\begin{array}{c}\text { Exopolysaccaharides } \\
\text { (EPS) }\end{array}$ & Bio-lubricant & Borah et al. (2018) \\
\hline Scenedesmus sp., & Lipid & Biofuels & $\begin{array}{c}\text { Contreras-Angulo et } \\
\text { al. (2019) }\end{array}$ \\
\hline Chlamydomonas reinhardtii & Acetic acid & Hydrogen gas & $\begin{array}{l}\text { Fakhimi \& Tavakoi } \\
\text { (2019) }\end{array}$ \\
\hline
\end{tabular}




\section{The greenwater application}

This technique involves the natural assemblages of microalgae to feed for commercialised finfish larvae directly (Neori, 2010). Tetraselmis sp., Isochrysis sp. and Nannochloropsis $s p$. are among the suitable microalgae species for this purpose. In Korea, Japan and China, this technique is already being applied as it improved water quality, aquatic organism's survival and growth rate (Neori 2010). Further research on the understanding of the interaction between aquatic organisms and population of algae, the ways to control and manage them, the location of the farm for proper dispersal of waste and fitting technology could help in establishing this method.

\section{Live feed}

Live feed usually preferred by the aquatic larvae organisms when their feeding ability is not yet developed. Most aquatic larvae have an incomplete digestive system, small mouth size for feeding upon hatching. Proper handling technique and technology is needed to ensure the balanced nutrition is delivered to the larvae (Brown, 2002). Whole microalgae cells are sufficient to fulfil fish larvae diet. Therefore, live microalgae are often used as a feed. The criteria for suitable microalgae to be used as live feed are it must be easily digested, high growth rate and contain proper nutrition (Brown, 2002). Microalgae are used as tools to deliver important nutrients like PUFA (SC-PUFA and HUFA) and FAA to fish larvae through natural live prey (rotifer, brine shrimp, daphnia and etc.) because naturally these live preys are missing with important nutrients for fish larvae ( $\mathrm{Vu}$ et al., 2019). Microalgae can serve as a complementary diet for these natural live preys prior to feeding to fish larvae in the hatchery. It is estimated that more than 40 species of microalgae have been isolated and cultivated as pure strains in intensive systems (Becker, 2004; Shield \& Lupatsch, 2012). The most common species used in commercial mariculture are diatoms Skeletonema costatum, Thalassiosira pseudonana, Chaetoceros gracilis, C. calcitrans, the flagellates Isochrysis galbana, Tetraselmis suecica, Monochrysis lutheri, Nannochloropsis spp., and the benthic diatoms Nitzschia palaecea and N. closterium (Becker, 2004).

\section{B. Biohydrogen Producer}

Lage et al. (2018) pointed out that microalgae biomass grown in wastewater is not suitable to be used as food, feed, or biofertiliser instead be used as a source of energy. The increasing demand for energy and depleted natural resources for energy production has initiated the search for alternative green energy resources. Some green microalgae, cyanobacteria and photosynthetic \& non-photosynthetic bacteria are capable of producing biohydrogen gas (Khetkorn et al., 2017). The mechanism of hydrogen gas production in microalgae is facilitated through the action of hydrogenase enzyme that is produced under specific favourable condition. Several microalgae that may possess a hydrogenase enzyme for hydrogen production are identified from the species of Anabaena, Botryococcus, Chlamydomonas, Chlorella, Nostoc, Scenedesmus, Tetraspora and etc.

Due to high production cost and low production yield, commercial hydrogen production from microalgae biomass is still under ongoing studies. Nevertheless, with the current advancement of metabolic and genetic engineering approaches, more efficient biohydrogen production from microalgae and other microorganism is expected from the future. By studying the microalgae composition, the biochemical content of protein, carbohydrate and lipid is known to be dependent on growth conditions and microalgae species. Xiao et al. (2010) evaluated that glucose was able to produce 18 times more hydrogen gas in thermal treated sludge. This is because Hydrogen Producing Bacteria (HPB) can hydrolyse sugar faster during the dark fermentation process (Bai et al., 2004).

\section{Biofertiliser for Agriculture}

The controversial issue of using chemical fertiliser can be easily tackled using microalgae grown in wastewater. The subsequent biomass produced from the wastewater treatment could be used as cheap biofertiliser in the agriculture sector. Biological material with high concentrations of sequestered plant nutrients and fertiliser from microalgae biomass could reduce the cost and dependency on conventional fertiliser. Unfortunately, there is limited research on evaluating the performance efficacy of 
these materials like fertilisers, specifically in horticultural applications.

Nowadays, the introduction of biofertiliser has emerged as highly sustainable agriculture due to its green resource, cheap and non-toxic properties. By having a less negative impact on the environment and greener alternative for the agriculture sector, biofertiliser is considered superior over conventional chemical fertiliser in agriculture (Chatterjee et al., 2017). Banayo et al. (2012) simplified biofertiliser as free-living organisms associated with root surfaces. Still, they may also contain endophytes microorganisms which able to colonise the intercellular and intracellular spaces of plant tissues without causing apparent damage to the host plant. The microorganisms, which are commonly used as biofertilisers, belong to families of bacteria, blue-green algae and fungi (Mazid \& Khan, 2014). Algal biofertiliser is believed to improve the quality of soil by separating the sodium salt from the soil and convert alkaline soil into fertility soil (Embrandiri et al., 2012). The potential to mobilise insoluble forms of inorganic phosphates to restore soil nutrients by secreting exopolysaccharides and bioactive substances into the agricultural soil has nominated the blue-green algae (BGA) as a suitable candidate for biofertiliser (Chatterjee et al., 2017).

A study conducted by Garcia-Gonzalez and Sommerfeld (2015) utilising dried green alga Acutodesmus dimorphuswere as a primer for plant seeds, foliar spray, and biofertiliser was found to enhance seed germination, plant growth and floral production in tomatoes. Another study conducted by Subramanian and Jayasingam (2017) reported potential usage of marine microalgae as alternative fertiliser in maize cultivation by enhancing high growth and yield, which require further study to produce microalgae-based fertiliser composition. It also believes that some red algae used as biofertilisers also helps to increase the growth nutritional value and yield of agriculture plants (Chatterjee $e t$ al., 2017). Mazid and Khan (2014) reported that combination of algae and rock phosphate improved rice straw and grain yield production as phosphate promotes root and height development, fresh bulb weight, root colonisation and phosphate uptake of wheat plants (Mazid \& Khan, 2014).

Biofertiliser can be presented in liquid or solid form. Liquid bio-fertilisers are formulations of special liquid containing desired microorganisms added with the unique chemical that act as cell protectants to the resting spores so that it becomes more tolerant to harsh condition and can last longer (Mazid \& Khan, 2014). The solid form of biofertiliser is always incorporated with a suitable carrier which their expiry period is only limited to 6 months depending on the type of carrier. The prolong use of microalgae as biofertiliser for 3 to 4 years is believed to lessen and completely eradicate the need to use any chemical fertiliser in the future.

\section{INTEGRATING WASTEWATER TREATMENT WITH AQUACULTURE AND AGRICULTURE APPLICATION: OLD CONCEPT WITH NEW APPLICATION}

The application of microalgae grown in wastewater (i.e., palm oil wastewater) can be integrated with the aquaculture and agriculture for more sustainable approaches by utilising waste material to sustain another activity. In Greece, the concept of integrated aquaculture for the last 30 years has been adopted to minimise the environmental impacts and simultaneously reduce the feeding cost (Vatsos et al., 2015). Meanwhile, the other parts of Asia are prevalent in applying rice-fish farming as an integrated production system (Halwart \& Gupta, 2004).

In Malaysia, approximately 3.75 tonnes of palm oil mill effluent (POME) was produced and requires a larger space of ponding system POME treatment (Ahmad et al., 2003). The treated wastewater and biomass produced should not be wasted; therefore, recent technology incorporating of POME treatment with microalgae seems promising. By integrating wastewater treatment with aquaculture and agriculture application, nothing will be wasted and at the same time can generate side income for smallholder farmers. This integration concept would benefit land used efficiency by using optimum space for installation. This method maximises resources utilisation by promoting crops diversity. Livestock production, well-organised land management and preventing any further destruction to the Earth to meet human's need for the future.

The circular valorisation or operational circularity concept is useful in attaining more sustainable approaches by converting waste material into beneficial product and enhance the economic growth among farmers (Figure 2). Utilisation of microalgae to treat POME is a good example of this concept. The treated wastewater will be fully utilised to 
fertilised crops and biomass produced as food for aquaculture organism. Hence, this concept promotes zero-waste application while reducing the dependency on chemical fertiliser and aquaculture artificial feed.

The overall integrated process is illustrated in Figure 3. This affordable integration system can be installed at a very lowcost with the appropriate technology. The concept of this process is to grow microalgae in the fish pond so it can consume the free flows of nutrient from fish manure. After several days cultivated in the fish pond, the cultured microalgae will be used to inoculate POME in the treatment ponds. The valuable microalgae biomass harvested from the treatment ponds can be utilised as fish feed, and simultaneously, the treated wastewater can be used to irrigate crops field. This process would minimise the negative impact associated with agricultural activities by reducing the GHGs emission and degrade the organic material present in POME effectively. With low energy consumption and labour force, this treatment system can be turned into high profitability business in the market, especially for rural farmers. It has a promising impact on the economy and social improvement among poor farmers. It has more potential in promoting more sustainable income with available waste resources and hence promoting more environmental-friendly integrated agriculture-aquaculture system. As a result, it can attract more collaboration between both conventional farmers and fish farmer to share their water resources to overcome waters scarcity issue.

The concept of integrating wastewater treatment with aquaculture and agriculture application has been put forward in this paper to give a social benefit, especially for rural communities. It is a win-win situation where the industry gets to eliminate wastewater, and society gets to increase its in-house income. The main idea in this system is to reduce the impact of wastewater on the environment by converting it into useful products and to maximise the production of the crop. This concept embarks with the higher sustainability approach to improve food security for the future generation and ensure the land availability is well sustained.

\section{STRATEGIES TO INCREASE YIELD OF MICROALGAE BIOMASS}

Traditional methods of microalgae cultivation for commercialisation are always associated with low biomass yield, high operational costs, harvesting problems which often lead to poor techno-economic performance. Usually, algal storage causes nutrient degradation and affecting their maximum capabilities for utilisation. For various algal applications, it is essential to find ways which can increase the yield of microalgae biomass at its best. This includes cocultivation the microalgae with other organisms, manipulating microalgae growth conditions and improving culture system/design. Recently there has been growing interest in co-cultivation systems incorporating microalgae with fungi, yeast and bacteria to enhance biomass production, enhanced lipid production and decrease nutrient/energy inputs leading to low-cost installation and effective bioflocculation of microalgae biomass.

\section{A. Co-Cultivation}

The previous studies have proven microalgae-fungi cocultivation had improved the growth of microalgae, suggesting a potential for microalgae-fungal symbiosis (Simpson, 2018; Zhou et al., 2018). Fungi are unique; the filamentous structure allows them to self-pelletise eases harvesting process in algae-fungi co-cultivation system. The coagulative machinery use spores for palletisation, whereas non-coagulative machinery consist of the germinated hyphae from the spores, which then will be interlinked to form pellets (Gultom \& $\mathrm{Hu}$, 2013). Fungi can metabolise glucose $\left(\mathrm{C}_{6} \mathrm{H}_{12} \mathrm{O}_{6}\right)$ and releases carbon dioxide $\left(\mathrm{CO}_{2}\right)$. Later, microalgae assimilate $\mathrm{CO}_{2}$ through photosynthesis to release oxygen gasses $\left(\mathrm{O}_{2}\right)$. Ammonia is produced when microalgae metabolised $\mathrm{NO}^{2-}$ to and taken up by fungi as a nutrient (Hom and Murray 2014). Few fungal such as Aspergillus spp, Basidiomycete spp, Phanerochaete spp shows coagulative ability which causes the cell to aggregate into lumps (Wrede et al., 2014). Microalgae-fungi cultivation is being used for many environmental applications (i.e., bio-flocculation, nutrient and $\mathrm{CO}_{2}$ removal in wastewater treatment, wastewater pre-treatment, and in aquaculture application) (Ummalyma et. al., 2017; Zhou et al., 2018). It was found that bio-flocculation of microalgae cell using fungi are superior 
method in term of its economics, harvesting efficiency, technological possibilities (Ummalyma et al., 2017). Besides, their co-production of value-added product form the symbiotic of microalgae with fungal has been industrially utilised for its astaxanthin production (Dong \& Zhao 2004), biodiesel (Shu et al., 2013), lipid and carotenoid (Santos et al., 2013), and as a model for micro-ecosystem (Hom \& Murray 2014).

Co-cultivation of microalgae with bacteria has been reported to cause both stimulation and inhibition effect to microalgae growth. Some bacteria are capable of killing microalgae by producing an enzyme that can break the algal cell wall and cause algal lysis (Morris, 1962; Cole, 1982; Fergola et al., 2007). Bacteria stimulates microalgae growth by degrading the intractable compounds (i.e., ammonium, nitrogen, phosphate and carbon dioxide) for nutrient absorption and in returns, microalgae provide essential nutrients (i.e., Vitamin B12) for bacteria (Croft et. al., 2005;
Zhang et al., 2012). However, not all microalgae-bacteria interaction stimulates microalgae growth. Fakhimi and Tavakolia (2019) had shown the effect of bacteria cocultivation of Chlamydomonas reinhardtii with Escherichia coli, Pseudomonas stutzeri and Pseudomonas putida enhanced hydrogen production up to $56 \%$ but reduced the growth of Chlamydomonas.

Co-cultivation of microalgae with yeast has proven to improve about $40-50 \%$ of biomass and $60-70 \%$ of total lipid in $5 \mathrm{~L}$ photobioreactor cultivation (Yen et al., 2015). The mechanism involves between algae-yeast co-culture system are the result of gas utilisation and providing of trace elements to each other after the natural cells lysis (Yen et al., 2015). Microalgae-yeast co-culture is also beneficial for wastewater treatment as it can remove $96 \%$ of nitrate, $100 \%$ of TAN and $93 \%$ of orthophosphate as it allows of aerobic fermentation condition (Walls et al., 2019).
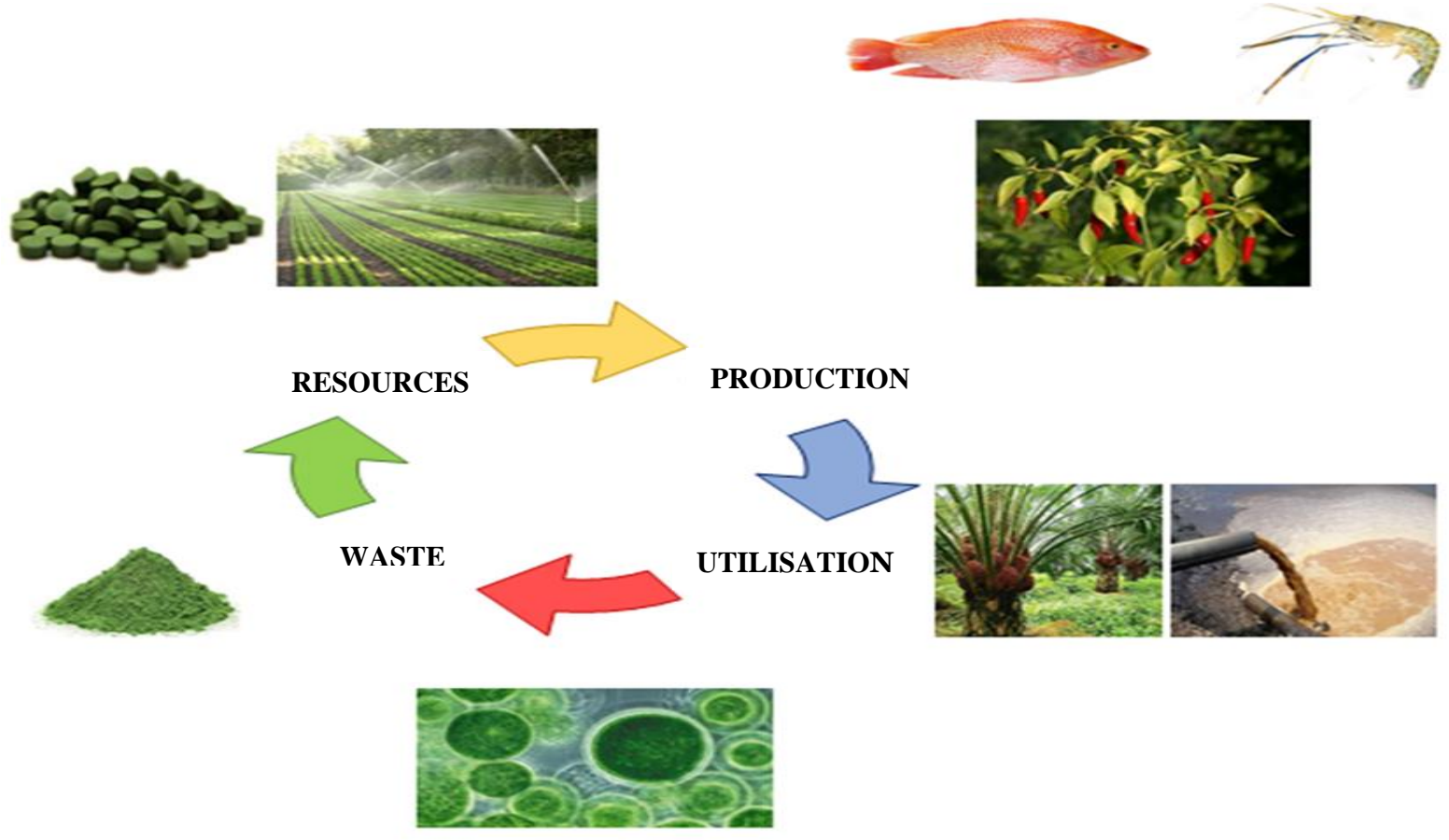

PRODUCTION

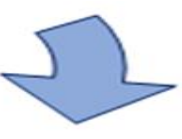

TILISATION
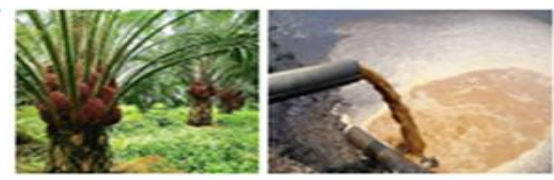

Figure 2. The operational concept of circularity 


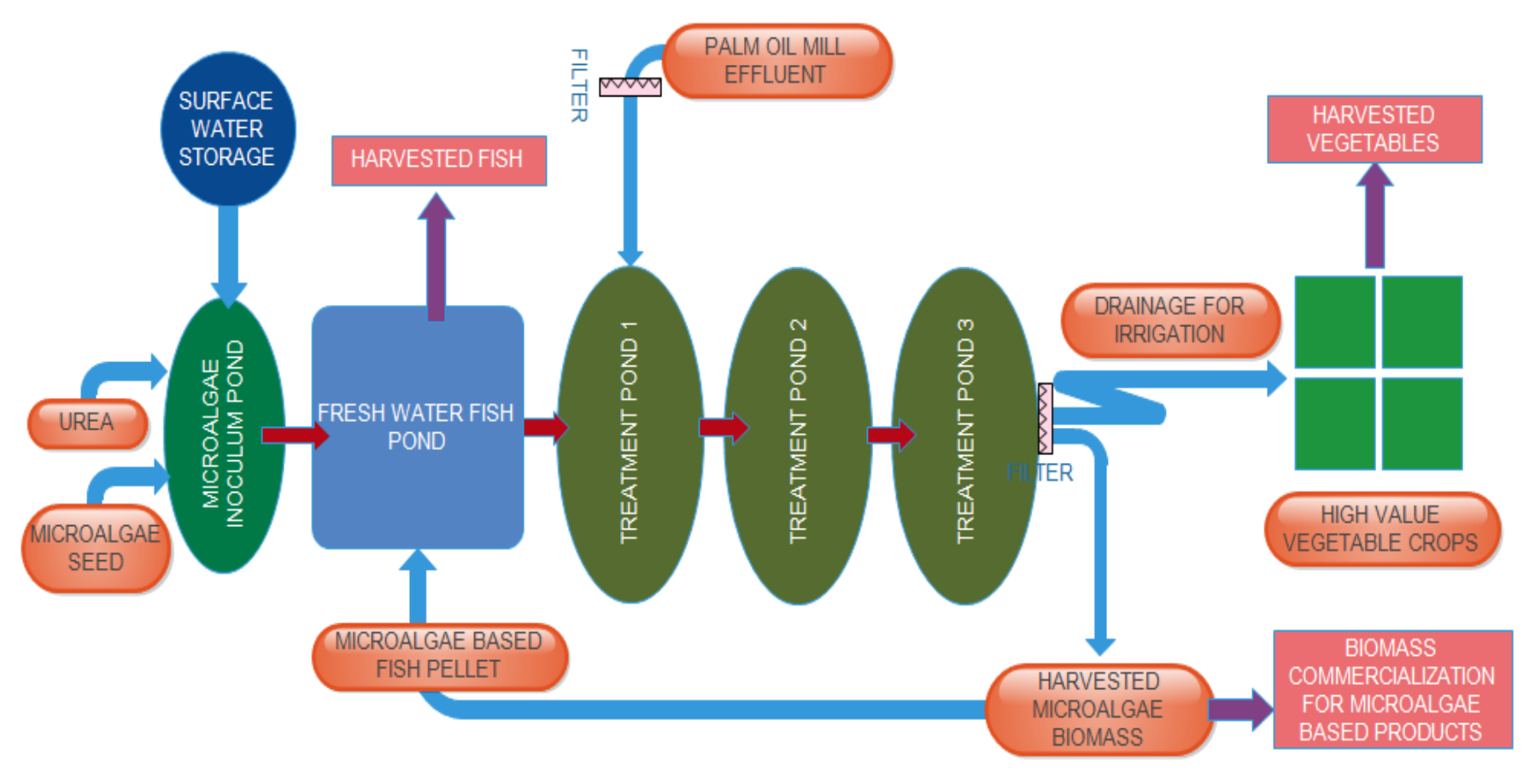

Figure 3. The overall process flow of the treatment system 


\section{B. Manipulating The Growth Conditions and Acclimatisation}

Four main microalgae conditions that can be manipulated for optimum growth are photoautotrophy, heterotrophy, mixotrophy and photo-heterotrophy (Chojnacka \& Noworyta, 2004). A study reported a 1.9-fold increment in biomass output was obtained by manipulating cultivation condition can maximising cost efficiency in industrial production at a large scale (Engin et al., 2017). Another study conducted by $\mathrm{Wu}$ and Shi (2007) on heterotrophic cultivation of Chlorella pyrenoidosa produced microalgae cell densities as high as 104.9 g.L-1 of dry weight while Gupta and Pawar (2018) found that mixotrophic cultivation of microalgae improved the quality of lipid and acetate. Ra et al. (2017) reported Isochrysis galbana, Phaeodactylum tricornutum and Nannochloropsis salina produced 1.03 g DCW/L, 0.95 g DCW/L, 0.85 g DCW/L, and 0.62 g DCW/L respectively when introduced with mix LED wavelength. Therefore, it is necessary to find economical and effective ways to increase the microalgae yield for commercial scale and to minimise the environmental impact using the methods discussed above.

Under normal culture condition, the differences in the growth medium and environment could challenge microalgae performance. Therefore, an acclimation step can be applied to help microalgae for better adapt to the new environment (Hu et al., 2019). The acclimatisation of microalgae has many potentials. For instance, the acclimatised Chlorella sp. to hypersaline condition offers a mean to reduce contamination (Anandraj et al., 2020). Hu et al. (2019) also reported acclimated S. obliquus, C. vulgaris and C. sorokiniana achieved higher biomass than those without acclimation thus remove organic pollutants efficiently and the biomass produced were used for further applications. Acclimation had successfully shortened the microalgae's lag time as proven by Khalid AAH et al. (2018) and further improvement of the microalgae growth are proven feasible. In short, the acclimatised microalgae can reduce or eliminate the high cost of energy-intensive microalgae processes.

\section{Culture System and Design}

The cultivation systems can be classified into three major systems, hybrid production systems (Medipally et al., 2015), closed and open system (Wu et al., 2012). Open-air systems in shallow ponds, tanks, circular ponds and raceway ponds are widely used to imitate the natural habitat of microalgae. This system is characterised by simple and inexpensive, but the biomass yield and system stability are more reduced than other systems (Borowitzka, 1999). Meanwhile, for closed culture system, the photobioreactors (PBR) are made of distinct configurations such as tubular, flat plate $\mathrm{CWu}$ et al., 2012), fluidised-bed bioreactors (FBR), parallel-plate bioreactors (PPR), air-lift bioreactors (ALR), hollow-fibre bioreactor (HFR) and column photobioreactors (Malik, 2002). Closed culture system allowing higher cell density at higher capital and operating cost but easier to control and manage (Wu et al., 2012). Nevertheless, the efficiency of phototrophic growth of microalgae in both systems subject to the light source and intensity (Medipally et al., 2015). Approximately 200-400 $\mu \mathrm{M}$ photons $\mathrm{m}^{-2} \mathrm{~s}^{-1}$ average of light intensity, required by most of algae species to obtain the maximum photosynthesis (Medipally et al., 2015). Better results could be obtained by combining both open and closed culture system (hybrid system). In a hybrid system, the required amount of contamination-free inocula obtained from photobioreactors is transferred to open ponds or raceways to get higher biomass output (Grobbelaar, 2000; Greenwell et al., 2009). This system was used by Olaizola (2000) and Huntley and Redalje (2007) in the production of astaxanthin from Haematococcus pluvialis. However, this system is more expensive, and it is also a batch culture system rather than a continuous culture system.

\section{Strain Improvement by Metabolic Engineering}

Recent technology advancement in microalgae is aimed in the improvement of microalgae biomass productivity. The utilisation of numerous genomic tools and advance biotechnology methods such as synthetic gene construction and manipulation of metabolic pathways empowered growth of cell production and its metabolic activity (Jagadevan et al., 2018). Improving strain development is the main focus in most of the metabolic engineering studies and necessitates reliable tools, knowledge and resources which are very limited at the moment. Maximising algal growth and its metabolic output through metabolic engineering is future feasibility as a substitution to the non-renewable fossil fuels. Further research in this technology is essential, particularly 
in commercial-scale on productions of biofuels from microalgae concurrently obtaining maximisation profit output (Medipally et al., 2015).

\section{E. Nutrient Supplementation And Chemical Enhancer}

The growth of microalgae in wastewater media might be limited, but nutrient supplementation is always helpful in enhancing the microalgae biomass. Ansari et al. (2017) used sodium nitrate supplementation in aquaculture wastewater to improve the productivities of biomass, lipid, carbohydrate and protein. The result showed the biomass productivity of Ankistrodesmus falcatus and Chlorella sorokiniana were comparable with synthetic media cultivation. Research conducted by Cheah et al. (2018) was done to enhance the production of biomass and lipid in microalgae cultured in POME using nutrient supplementation of glucose, urea and glycerol. This study found that glycerol had higher growth performance as compared to the other supplementation. However, the lipid production was enhanced when supplemented with the mixture of urea, glucose and glycerol supplementation.

Various enhancer chemicals had proven effective and economical for large scale cultivation. The chemicals are classified into four categories: chemicals regulating biosynthetic pathways, chemicals inducing oxidative stress responses, phytohormones and analogues regulating multiple aspects of microalgae metabolism, and chemicals directly as metabolic precursors (Yu et al., 2015). Herein is the summarised chemical used in enhancing the microalgae products (Table 6).

\section{FUTURE PERSPECTIVE}

Overall, the utilisation of wastewater in media cultivation for microalgae is restricted due to the expensive treatment and safety concern. However, this pitfall can be reduced in the future together with a further intensive scientific study, advanced technology, a better management system and applying better standard protocol. The utilisation of microalgae cultured in wastewater is still limited to certain microalgae species. Therefore, a new local species with improved characteristics and nutrient qualities could improvise the utilisation of microalgae grown in the targeted wastewater. Apart from this, the type of wastewater used to grow microalgae should be diversified not only limited to agriculture wastewater. The characteristic of the wastewater should be well studied. More research should be conducted on the interaction of microalgae with another organism as they can produce valuable substances from the interaction, such as the production of the certain antibiotic. At the same time, a major problem in rural agriculture with untreated agro-waste that contribute to environmental pollution can be reduced with the full utilisation of agro-waste usage.

\section{CONCLUSION}

Agriculture wastewater management is the bottleneck when agriculture activity is the main economic activities. Recent trends have highlighted that microalgae have the potential to remediate wastewater and can turn into profitable biomass. It is feasible to integrate microalgal cultivation in wastewater for green energy production and waived the security and toxicity concern. Still, for other purposes like for animal feed production, additional efforts must be put to secure the security concern. Therefore, a clear picture of multiples strategies to turn microalgae biomass into multiple applications, especially in agriculture and aquaculture has been set forth in this paper. This study concludes that with a considerable effort, agriculture wastewater can be used as microalgae feedstock for co-production of value-added products from microalgae biomass provided appropriate treatment and ways to increase microalgae yield is optimised.

\section{ACKNOWLEDGEMENT}

We gratefully acknowledged the financial support from Geran Universiti Penyelidikan (GUP-2018-092) from Universiti Kebangsaan Malaysia. 
Table 6. Chemicals used to enhance growth and products in microalgae (Yu et. al., 2015; Cho et al., 2019).

\begin{tabular}{|c|c|c|}
\hline Species & Products & Chemicals \\
\hline Chlorella vulgaris & Biomass & $\begin{array}{l}\text { Brassinosteroids (BRs) } \\
\text { Indomethacin (IM) } \\
\text { Salicylic acid (SA) } \\
\text { Diamines, polyamines } \\
\text { Zeatin }\end{array}$ \\
\hline Haematococcus pluvialis & Astaxanthin & $\begin{array}{l}\text { Salicylic acid (SA) } \\
\text { 2, 4-Epibrassinolide (EBR) Jasmonic acid (JA) } \\
\text { Salicylic acid (SA) } \\
\text { Methyl jsmonate (MJ), gibberellic acid (GA3) }\end{array}$ \\
\hline Schizochytrium sp. $H X-308$ & DHA & Ethanol, sodium acetate, malic acid \\
\hline Scenedesmus obliquus & Biomass & Methanol \\
\hline Chlorella sorokiniana & Biomass and lipid & $\begin{array}{l}\text { 2-phenylacetic acid (PAA), Indole butyric acid (IBA), 1-naphthaleneacetic acid (NAA), } \\
\text { Gibberellic acid (GA3), Zeatin, thidiazuron, Humic acid, Kelp extract, Methanol, Fe, } \\
\text { Putrescine, Supermidine }\end{array}$ \\
\hline Spirulina platensis & $\begin{array}{l}\text { Total carotenoids and } \alpha \text {-tocopherol, glutathione } \\
\text { (GSH), and ascorbic acid (AsA) }\end{array}$ & $\mathrm{H}_{2} \mathrm{O}_{2}$ \\
\hline Dunaliella salina & Biomass and glycerol & Copper \\
\hline Chlorella vulgaris & Lipid & $\mathrm{Fe}$ \\
\hline Chlamydomonas reinhardtii & Biomass and fatty acid & Indole acetic acid (IAA), gibberellic acid (GA3), kinetin, 1-triacontanol, abscisic acid \\
\hline Schizochytrium sp. $H X-308$ & DHA & $\begin{array}{l}\text { Malic acid (MA) } \\
\text { ethanol }\end{array}$ \\
\hline Chlorella vulgaris & Biomass and lipid & Bacterial volatile compounds \\
\hline
\end{tabular}




\section{REFERENCES}

Abelleira-Pereira, JM, Pérez-Elvira, SI, Sánchez-Oneto, J, Cruz, RDL, Portella, JR \& Nebot, E 2015, 'Enhancement of methane production in mesophilic anaerobic digestion of secondary sewage sludge by advanced thermal hydrolysis pretreatment', Water Research, vol. 71, pp. 330-340.

Ahmad, AL, Ismail S \& Bhatia, S 2003, 'Water recycling from palm oil mill effluent (POME) using membrane technology', Desalination, vol. 157, no. 1-3, pp. 87-95.

Ahluwalia, SS \& Goyal, D 2007, 'Microbial and plant derived biomass for removal of heavy metals from wastewater', Bioresource Technology, vol. 98, no. 12, pp. 2243-2257.

Anandraj, A, White, S, Naidoo, D \& Mutanda, T 2020, 'Monitoring the acclimatization of a Chlorella sp. from freshwater to hypersalinity using photosynthetic parameters of pulse amplitude modulated fluorometry', Bioresource Technology, vol. 309.

Ansari, FA, Singh, P, Guldhe, A \& Bux, F 2017, 'Microalgal cultivation using aquaculture wastewater: integrated biomass generation and nutrient remediation', Algal Research, vol. 21, pp. 169-177.

Abinandan, S \& Shanthakumar, S 2015, 'Challenges and opportunities in application of microalgae (Chlorophyta) for wastewater treatment: a review', Renewable and Sustainable Energy Reviews, vol. 52, pp. 123-132.

Achyuthan, KE, Harper, JC \& Manginell, RP \& Moorman, MW 2017, 'Volatile metabolites emission by in vivo microalgae-an overlooked opportunity?', Metabolites, vol. 7, no. 3, pp. 39.

Andreotti, V, Chindris, A \& Brundu, G, Vallainc, D, Francavilla, M, Garcia \& Joan 2017, 'Bioremediation of aquaculture wastewater from Mugil cephalus (Linnaeus, 1758) with different microalgae species', Chemistry and Ecology, vol. 33, no. 8, pp, 750-761.

Apandi, N, Radin-Mohamed, RMS \& Al-Gheethi, A, Latiffi, A, Arifin, SNH \& Ghani, P 2018, 'Phycoremediation of heavy metals in wet market wastewater', IOP Conference Series: Earth and Environmental Science, vol. 140, pp. 1-7.

Anjum, M, Al-Makishah, NH \& Barakat, MA 2016, 'Wastewater sludge stabilization using pre-treatment methods', Process Safety and Environmental Protection, vol. 102, pp. 615-632.

Bai, MD, Cheng, SS \& Chao, YC 2004, 'Effects of substrate components on hydrogen fermentation of multiple substrates', Water Science and Technology, vol. 50, no. 8, pp. 209-216.

Banayo, NPM, Cruz, PCS \& Aguilar, EA \& Haefele, SM 2012, 'Evaluation of biofertilizers in irrigated rice: effects on grain yield at different fertilizer rates', Agriculture, vol. 2, pp. 7386.

Becker, EW 2004, 'Microalgae for aquaculture: the nutritional value of microalgae for aquaculture', eds A Richmond, in Handbook of Microalgal Culture: Biotechnology and Applied Phycology, John Wiley \& Sons, Blackwell Publishing.

Bharathiraja, B, Chakravarthy, M \& Kumar, RR, Yogendran, D, Yuvaraj, D, Jayamuthunagai, J, Kumar, RP \& Palani, S 2015, 'Aquatic biomass (algae) as a future feed stock for biorefineries: a review on cultivation, processing and products', Renewable and Sustainable Energy Reviews, vol. 47, pp. 635-653.

Borah, D, Nainamalai, S \& Gopalakrishnan, S, Rout, J, Alharbi, NS \& Nooruddin T 2018, 'Biolubricant potential of exopolysaccharides from the cyanobacterium Cyanothece epiphytica', Applied Microbiology and Biotechnology, vol. 102, no. 8, pp. 3635-3647.

Borowitzka, MA 1999, 'Commercial production of microalgae: ponds, tanks, tubes and fermenters', Journal of Biotechnology, vol. 70, no. 1-3, pp. 313-321.

Brown, MR 2002, 'Nutritional value and use of microalgae in aquaculture', Memorias Del VI Simposium Internacional de Nutrición Acuícola, pp. 281-292.

Carballa, M, Duran, C \& Hospido, A 2011, 'Should we pretreat solid waste prior to anaerobic digestion? an assessment of its environmental cost', Environmental Science and Technology, vol. 45, no. 24, pp. 10306-10314.

Chatterjee, A, Singh, S, Agrawal, C, Yadav, S, Rai, R \& Rai, C 2017, 'Role of algae as a biofertilizer', Algal Green Chemistry, pp. 189-200.

Cheah, WY, Show, PL, Juan, JC, Chang, JS \& Ling, TC 2018, 'Enhancing biomass and lipid productions of microalgae in palm oil mill effluent using carbon and nutrient supplementation', Energy Conversion and Management, vol. 164, pp. 188-197.

Chiu, S, Kao, C \& Chen, T, Chang, YB, Kuo, CM \& Lin, CS 2014, 'Cultivation of microalgal Chlorella for biomass and lipid production using wastewater as nutrient resource', Bioresource Technology, vol. 184, pp. 179-189. 
Chinnasamy, S, Bhatnagar, A, Hunt, RW \& Das, KC 2010, 'Microalgae cultivation in a wastewater dominated by carpet mill effluents for biofuel applications', Bioresource Technology, vol. 101, no. 9, pp. 3097-3105.

Cho, K, Heo, J, Cho, D, Tran, QG, Yun, GH, Lee, SM, Lee, YJ \& Kim, HS 2019, 'Enhancing algal biomass and lipid production by phycospheric bacterial volatiles and possible growth enhancing factor', Algal Research, vol. 37, pp. 186194.

Cho, S, Luong, TT \& Lee, D, Oh, YK \& Lee, T 2011, 'Reuse of effluent water from a municipal wastewater treatment plant in microalgae cultivation for biofuel production', Bioresource Technology, vol. 102, no. 18, pp. 8639-8645.

Choi, H \& Lee, S 2012, 'Effects of microalgae on the removal of nutrients from wastewater: various concentrations of Chlorella vulgaris', Environ. Eng. Res., vol. 17, no. S1.

Chojnacka, K \& Noworyta, A 2004, 'Evaluation of Spirulina sp. growth in photoautotrophic, heterotrophic and mixotrophic cultures', J. Appl. Phycol, vol. 34, no. 2, pp, 461-465.

Cole, JJ 1982, 'Interactions between bacteria and algae in aquatic ecosystems', Annu. Rev. of Ecol. and Syst, vol. 13, pp. 291-314.

Contreras-Angulo, JT, Mata, T, Cuellar-Bermudez, SP, Caetano, NS, Chandra, R, Garcia-Perez, JS, Muylaert, K \& Para-Saldivar, $\mathrm{R}$ 2019, 'Symbiotic co-culture of Scenedesmus sp. and Azospirillum brasilense on ndeficient media with biomass production for biofuel', Sustainability, vol. 11, no. 3, pp. 707.

Croft, MT, Lawrence, AD, Raux-Deery, E, warren, MJ \& Smith, AG, 2005, 'Algae acquire vitamin B12 through a symbiotic relationship with bacteria', Nature, vol. 438, pp. 90-93.

Dalrymple, OK, Halfhide, T, Udom, I, Gilles, B, Wolan, J, Zhang, Q \& Ergas, S 2013, 'Wastewater use in algae production for generation of renewable resources: a review and preliminary results', Aquatic Biosystems, vol. 9, no. 1, pp. 1-11.

Demirbas, A 2010, 'Use of algae as biofuel sources', Energy Conversion and Management, vol. 51, no. 12, pp, 27382749.

Demirbas, MF 2011, 'Biofuels from algae for sustainable development', Applied Energy, vol. 88, no. 10, pp. 34733480 .

Delrue, F, Álvarez-Díaz, PD, Fon-Sing, S, Fluery, G \& Sassi, JF 2016, 'The environmental biorefinery: using microalgae to remediate wastewater, a win-win paradigm', Energies, vol. 9, no. 3, pp. 132.

Dineshkumar, R, Kumaravel, R, Gopalsamy, J \& Sikder, MNA2017, 'Microalgae as bio-fertilizers for rice growth and seed yield productivity', Waste and Biomass Valorization vol. 9 , no. 5, pp. 1-8.

Diprat, AB, Menegol, TJ, Boelter, JF, Zmozinki, A, Goreti, M, Vale, R Rodrigues, E \& Rech, R 2017, 'Chemical composition of microalgae Heterochlorella luteoviridis and Dunaliella tertiolecta with emphasis on carotenoids', Journal of the Science of Food and Agriculture, vol. 97, no. 10, pp. 3463-3468.

Dong, QL \& Zhao, XM 2004, 'In situ carbon dioxide fixation in the process of natural astaxanthin production by a mixed culture of Haematococcus pluvialis and Phaffia rhodozyma', Catalysis Today, vol. 98, no. 4, pp. 537-544.

Drews, P, Colares, RG, Machado, P, Faria, MD, Detoni, A \& Tavano V 2013, 'Microalgae classification using semisupervised and active learning based on Gaussian mixture models', Journal of the Brazilian Computer Society, vol. 19, no. 4, pp. 411-422.

Embrandiri, A, Rupani, P, Quaik, S, Ibrahim, MH \& Singh, SP 2012, 'Environmental sustainability in the palm oil industry ; palm waste as nutrient supplement and effects on plant growth characteristics', International Conference of Environmental, Biomedical and Biotechnology, vol. 41, pp. 41-45.

Engin, IK, Cekmecelioglu, D, Yücel, AM \& Oktem, HA 2017, 'Enhancement of heterotrophic biomass production by Micractinium sp. MEo5', Waste and Biomass Valorization, vol. 9, no. 5, pp. 811-820.

Fakhimi, N \& Tavakolia, O 2019, 'Improving hydrogen production using co-cultivation of bacteria with Chlamydomonas reinhardtii microalga', Materials Science for Energy Technologies, vol. 2, no. 1, pp. 1-7.

Fernandez, FGA, Cintia, G \& Frenandez-Sevilla, JM 2018, Recovery of nutrients from wastewaters using microalgae, Front. Sustain. Food Syst.

Fergola, P, Cerasuolo, M, Pollio, A, Pinto, G \& Dellagreca, M 2007, 'Allelopathy and competition between Chlorella vulgaris and Pseudokirchneriella subcapitata: Experiments and mathematical model', Ecol. Model, vol. 208, pp. 205214.

Field, CB 1998, 'Primary production of the biosphere: integrating terrestrial and oceanic components', Science, vol. 281, no. 5374, pp. 237-240. 
Gani, P, Sunar, NM, Peralta, HMM \& Latif, ABA 2016, 'Application of phycoremediation technology in the treatment of food processing wastewater by freshwater microalgae Botryococcus sp.', Journal of Engineering and Applied Sciences, vol. 11, no. 11, pp. 7288-7292.

Garcia-Gonzalez, J \& Sommerfeld, M 2015, 'Biofertilizer and biostimulant properties of the microalga Acutodesmus dimorphus', J. Appl. Phycol., vol. 28, no. 2, pp. 1051-1061.

Gamaralalage D, Sawai O \& Nunoura, T 2019, 'Degradation behavior of palm oil mill effluent in Fenton oxidation', Journal of Hazardous Materials, vol. 364, pp. 791-799.

Gil, A, Siles, JA, Martín, MA, Chica, AF, Pastor, FS \& ToroBaptisa, E 2018, 'Effect of microwave pretreatment on semi-continuous anaerobic digestion of sewage sludge', Renewable Energy, vol. 115, pp. 917-925.

Greenwell HC, Laurens LML, Shields RJ, Lovitt, RW \& Flynn, KJ 2009, 'Placing microalgae on the biofuels priority list: a review of the technological challenges', Journal of the Royal Society Interface, vol. 7, no. 46, pp. 703-726.

Grobbelaar, JU 2000, 'Physiological and technological considerations for optimising mass algal cultures', Journal of Applied Phycology, vol. 12, no. 3-5, pp. 201-206.

Guedes, AC, Sousa-Pinto, I \& Malcata, FX 2015, Application of Microalgae Protein to Aquafeed, in Handbook of marine microalgae (pp. 93-125), Academic Press.

Gupta, S \& Pawar, SB 2018, 'Mixotrophic cultivation of microalgae to enhance the quality of lipid for biodiesel application: effects of scale of cultivation and light spectrum on reduction of $\alpha$-linolenic acid', Bioprocess and Biosystems Engineering, vol. 41, no. 4, pp. 531-542.

Gultom, SO \& Hu, B 2013, 'Review of microalgae harvesting via co-pelletization with filamentous fungus', Energies, vol. 6, no. 11, pp. 5921-5939.

Halwart, M \& Gupta, MV 2004, 'Culture of fish in rice fields', FAO/The World Fish Center, Rome.

Hariz, HB, Takriff, MS, Yasin, NHM, Ba-Abbad, MN \& Mohammad Hakimi, NIN 2019, 'Potential of the microalgae-based integrated wastewater treatment and $\mathrm{CO} 2$ fixation system to treat Palm Oil Mill Effluent (POME) by indigenous microalgae; Scenedesmus sp. and Chlorella sp., Journal of Water Process Engineering, vol. 32, pp. 100907.

Hammadi, L, Ponton, A \& Belhadri, M 2012, 'Effects of heat treatment and hydrogen peroxide ( $\left.\mathrm{H}_{2} \mathrm{O} 2\right)$ on the physicochemical and rheological behavior of an activated sludge from a water purification plant,' Procedia Engineering, vol. 33, pp. 293-302.
Heimann, K \& Huerlimann, R 2015, 'Microalgal classification: major classes and genera of commercial microalgal species', ed $\mathrm{K}$ Se-Kwon, $\mathrm{K}$, in Handbook of Marine Microalgae: Biotechnology Advances, Academic Press, London.

Hemalatha, M, Sravan, JS, Min, B \& Mohan, SV 2019, 'Microalgae-biorefinery with cascading resource recovery design associated to dairy wastewater treatment', Bioresource Technology, vol. 284, pp. 424-429.

Hende, SVD, Claessens, L, Muylder, ED, Boon, N \& 2014, 'Microalgal bacterial flocs originating from aquaculture wastewater treatment as diet ingredient for Litopenaeus vannamei (Boone)', Aquaculture Research, vol. 47, no. 4, pp. 1075-1089.

Hom, EFY \& Murray, AW 2014, 'Niche engineering demonstrates a latent capacity for fungal-algal mutualism', Science, vol. 345, no. 6192, pp. 94-98.

$\mathrm{Hu}$, X, Meneses, YE, Stratton, J \& Wang, B 2019, 'Acclimation of consortium of micro-algae help removal of organic pollutants from meat processing wastewater', Journal of Cleaner Production, vol. 214, pp. 95-102.

Huntley, ME \& Redalje, DG 2007, 'CO2 mitigation and renewable oil from photosynthetic microbes: a new appraisal', Mitigation and Adaptation Strategies for Global Change, vol. 12, no. 4, pp. 573-608.

Jagadevan, S, Banerjee, A, Banerjee, C, Guria, C, Tiwari, R, Baweja, M \& Shukla, P 2018, 'Biotechnology for Biofuels Recent developments in synthetic biology and metabolic engineering in microalgae towards biofuel production', Biotechnology for Biofuels, vol. 11, no. 1, pp. 1-21.

Khalid, AAH, Yaakob, Z, Sheikh Abdullah, SR \& Takriff, MS 2018, 'Growth improvement and metabolic profiling of native and commercial Chlorella sorokiniana strains acclimatized in recycled agricultural wastewater', Bioresource Technology, vol. 247, pp. 930-939.

Khatoon, H, Banerjee, S, Syahiran, MS, Mat Nordin, N, Ambok Bolong, AN \& Endut A 2016, 'Re-use of aquaculture wastewater in cultivating microalgae as live feed for aquaculture organisms', Desalination and Water Treatment, vol. 57, pp. 29295-29302.

Khetkorn, W, Rastogi, RP, Incharoensakdi, A, Linblad, P, Madamwar, D, Pandet, A \& Larocche, C 2017, 'Microalgal hydrogen production - a review', Bioresource Technology, vol. 243, pp. 1194-1206.

Kim, MS, Lee, KM, Kim, HE, Lee, HJ, Lee, C \& Lee, C 2016, 'Disintegration of waste activated sludge by thermally activated persulfates for enhanced dewaterability', 
Environmental Science and Technology, vol. 50, no. 13, pp. 7106-7115.

Kumar, R \& Goyal, D 2010, 'Wastewater treatment and metal (Pb2+, Zn2+) removal by microalgal based stabilization pond system', Indian Journal of Microbiology, vol. 50, no. S1, pp. 34-40.

Kwang, HC, Lee, HJ, Koo, SY, Lee, DU \& Han, CH 2010, 'Optimization of pressurized liquid extraction of carotenoids and chlorophylls from Chlorella Vulgaris', Journal of Agricultural and Food Chemistry, vol. 58, no. 2, pp. 793-797.

Koyande, AK, Chew KW, Rambabu, K, Tao, Y, Chu, DT \& Show, PL 2019, Microalgae: A potential alternative to health supplementation for humans, Food Sci. Hum. Wellness., 8, pp. 16-24.

Lage, S, Gojkovic, Z, Funk, C \& Gentili, F 2018, 'Algal biomass from wastewater and flue gases as a source of bioenergy', Energies, vol. 11, no. 3, pp. 664.

Lardon, L, Arnaud, H, Bruno, S, Steyer, JP \& Olivier, B 2009, 'Policy analysis life-cycle assessment of biodiesel production from microalgae', Environmental Science and Technology, vol. 43, no. 17, pp. 6475-6481.

Larsdotter, K, Wastewater Treatment with Microalgae-A literature review, Sol. Energy 2006, vol. 62, pp. 31-38.

Lenihan-Geels, G, Bishop, KS \& Ferguson, LR 2013, 'Alternative sources of omega-3 fats: can we find a sustainable substitute for fish?', Nutrients, vol. 5, no. 4, pp. 1301-1315.

Liu, J, Wei, Y, Li, K. Tong, J, Wang, Y \& Jia, R, 2016, 'Microwave-acid pretreatment: a potential process for enhancing sludge dewaterability', Water Research, vol. 90, pp. 225-234.

Liu, J, Yang, Q, Wang, D, Li, X, Li, X, Zhong, Y, Li, X \& Zeng, G, 2016, 'Enhanced dewaterability of waste activated sludge by Fe(II)-activated peroxymonosulfate oxidation', Bioresource Technology, vol. 206, pp. 134-140.

Liu, J, Qiu, W \& Wang, Y 2017, 'Fungal pretreatment of raw digested piggery wastewater enhancing the survival of algae as biofuel feedstock', Bioresources and Bioprocessing, vol. 4, pp. 6.

Loo, PL, Chong, VS \& Vikineswary, S 2012, 'Rhodovulum sulfidophilum, a phototrophic bacterium, grown in palm oil mill effluent improves the larval survival of marble goby Oxyeleotris marmorata', Aquaculture Research, vol. 44, no. 3, pp. 495-507.

Luo, Z, Wang, D, Yang, J, Huang, H \& Su, G 2019, 'The effect of fermented superphosphate pretreatment and step-feed mode on biological denitrification of piggery wastewater', Science of the Total Environment, vol. 665, pp. 724-730.

Maizatul, AY, Mohamed, Al-Gheethi, AA, Al-Gheethi, AA \& Hashim, MKA 2017, 'An overview of the utilisation of microalgae biomass derived from nutrient recycling of wet market wastewater and slaughterhouse wastewater', International Aquatic Research, vol. 9, no. 3, pp. 177-193.

Malik, N 2002, 'Biotechnological potential of immobilised algae for wastewater N, P and metal removal: a review', BioMetals, vol. 15, pp. 377-390.

Mazid, M \& Khan, TA 2014, 'Future of bio-fertilizers in Indian agriculture: an overview', International Journal of Agriculture \& Food Research, vol. 3, no. 3, pp. 10-23.

Medipally, SR, Yusoff, FM, Banerjee, S, Shariff, M, Medipally, SR, Yusoff, FM \& Shariff, M 2015, 'Microalgae as sustainable renewable energy feedstock for biofuel production', BioMed Research International, vol. 2015, pp. 1-13.

Mehmood, MA, Rashid, U, Ibrahim, M, Abbas, F \& Taufi, YH 2014, 'Algal biomass production using wastewater', eds $\mathrm{K}$ Hakeem, M Jawaid \& U Rashid, in Biomass and Bioenergy, Springer, Cham.

Min, M, Wang, L, Li, Y, Mohr, MJ, Hu, B, Zhou, W \& Ruan, $\mathrm{R}$, 2011, 'Cultivating Chlorella sp. in a pilot-scale photobioreactor using centrate wastewater for microalgae biomass production and wastewater nutrient removal', Applied Biochemistry Biotechnology, vol. 165, pp. 123-137. Mehdizadeh, SN, Eskicioglu, C, Bobowski, J \& Johnson, T 2013, 'Conductive heating and microwave hydrolysis under identical heating profiles for advanced anaerobic digestion of municipal sludge', Water Research, vol. 47, no. 14, pp. 5040-5051.

Morris, RSS 1962, 'Evaluation of natural products for algicidal properties', Appl. Environ. Microbiol., vol. 10, pp. 289-292.

Muylaert, K, Beuckels, A, Depraetere, OI, Foubert I, Markou G \& Vandamme D 2015, 'Wastewater as a source of nutrients for microalgae biomass production', eds $\mathrm{N}$ Moheimani, M McHenry, K de Boer \& P Bahri, in Biomass and biofuels from microalgae, Springer International Publishing, Cham.

Nascimento, TA, Mejía, FR, Fdz-Polanco, F \& Miranda, MP 2017, 'Improvement of municipal wastewater pretreatment by direct membrane filtration', Environmental Technology, vol. 38, no. 20, pp. 2562-2572.

Ndukwe, GI, Mustapha, KB \& Ayo, RI 2012, 'Constraints to large scale algae biomass production and utilization', 
Journal of Algal Biomass Utilization, vol. 3, no. 2, pp. 1432.

Neori, A 2010, 'Greenwater aquaculture: the largest aquaculture sector in the world aquaculture', Journal of Applied Phycology, vol. 23, no. 1, pp. 143-149.

Nur, MMA \& Buma, AGJ, 2018, 'Opportunities and challenges of microalgal cultivation on wastewater, with special focus on palm oil mill effluent and the production of high value compounds', Waste and Biomass Valorization, vol. 10, no. 8, pp. 2079-2097.

Olaizola, M 2000, 'Commercial production of astaxanthin from Haematococcus pluvialis using 25,000-liter outdoor photobioreactors', Journal of Applied Phycology, vol. 12, no. 3-5, pp. 499-506.

Oz, NA \& Uzun, AC 2015, 'Ultrasound pretreatment for enhanced biogas production from olıve mill wastewater', Ultrasonics Sonochemistry, vol. 22, pp. 565-572.

Panigrahi, S \& Dubey, BK 2019, 'Electrochemical pretreatment of yard waste to improve biogas production: understanding the mechanism of delignification and energy balance', Bioresource Technology, vol. 292, pp. 121958.

Patrick, S \& Barbara, O 2005, 'Manufacturing microalgae for skin care', Cosmetic \& Toiletries Magazines, vol. no. 3, pp. 99-106 (magazine)

Plaza, M, Santoyo, S \& Jaime, L, Garcia-Blairsy Reina, G, Herrero, M, Senorans, FJ \& Ibanez, E 2010, 'Screening for bioactive compounds from algae', Journal of Pharmaceutical and Biomedical Analysis, vol. 51, pp. 450455 .

Priyadarshani, L \& Rath, B 2012, 'Commercial and industrial applications of micro algae - a review', Journal of Algal Biomass Utilization, vol. 3, no. 4, pp. 89-10o.

Prarthana, J \& Maruthi, KR 2019, 'Fresh water algae as a potential source of bioactive compounds for aquaculture and significance of solvent system in extraction of antimicrobials', Asian Journal of Scientific Research, vol. 12, pp. 18-28.

Qin, L, Shu, Q, Wang, Z, Shang, C, Zhu, S, Xu, J \& Yuan, Z 2014, 'Cultivation of Chlorella vulgaris in dairy wastewater pretreated by UV irradiation and sodium hypochlorite', Applied Biochemistry and Biotechnology, vol. 172, no. 2, pp. 1121-1130.

Rathod, H 2015, Algae Based Wastewater Treatment, Indian Institut of Technology Roorkee.

Ravindran, B, Gupta, SK, Cho, WM, Kim, JK, Lee, SR, Jeong, $\mathrm{KH} \&$ Choi, HC 2016, 'Microalgae potential and multiple roles-current progress and future prospects-an overview', Sustainability, vol. 8, no. 12, pp. 1-16.

Ra, CH, Sirisuk, P, Jung, JH, Jeong, GT \& Kim, SK 2017, 'Effects of light-emitting diode (LED) with a mixture of wavelengths on the growth and lipid content of microalgae', Bioprocess and Biosystems Engineering, vol. 41, no. 4, pp. 457-465.

Relicardo, $M$ 2015, 'Feed formulation for sustainable aquaculture. Proceeding International Workshop on Resource Enhancement and Sustainable Aquaculture Practices in Southeast Asia 2014.

Roy, JJ, Sun, L \& Ji, L 2014, 'Microalgal proteins: a new source of raw material for production of plywood adhesive', Journal of Applied Phycology, vol. 26, no. 3, pp. 1415-1422.

Ruiz-Hernando, M, Martinez-Elorza, J, Labanda, J \& Llorens, J 2013, 'Dewaterability of sewage sludge by ultrasonic, thermal and chemical treatments', Chemical Engineering Journal, vol. 230, pp. 102-110.

Safafar, H, Nørregaard, PU, Ljubic, A, Møller, P, Holdt, SL \& Jacobsen, C 2016, 'Enhancement of protein and pigment content in two Chlorella species cultivated on industrial process water', Journal of Marine Science and Engineering, vol. 4, no. 4, pp. 84 .

Safi, C, Zebib, B, Merah, O, Pontalier, PY, \& Vaca-Garcia, C 2014, 'Morphology, composition, production, processing and applications of Chlorella vulgaris: a review', Renewable and Sustainable Energy Reviews, vol. 35, pp. 265-278.

Santos, CA, Caldeira, ML, da Silva, TL, Novais, JM \& Reis, A 2013, 'Enhanced lipidic algae biomass production using gas transfer from a fermentative Rhodosporidium toruloides culture to an autotrophic Chlorella protothecoides culture', Bioresource Technology, vol. 138, pp. 48-54.

Sathasivam, R, Radhakrishnan, R, Hashem, A \& Abd_Allah, EF 2017, 'Microalgae metabolites: a rich source for food and medicine', Saudi Journal of Biological Sciences, vol. 26, no. 4, pp. 709-722.

Shamsudin, L 1992, 'Lipid and fatty acid composition of microalgae used in Malaysian aquaculture as live food for the early stage of penaeid larvae', Journal of Applied Phycology, vol. 4, no. 4, pp. 371-378.

Shields, RJ \& Lupatsch, I 2012, 'Algae for aquaculture and animal feeds', eds CW Posten, in Microalgal Biotechnology: Integration and Economy, De Gruyter.

Shu, CH, Tsai, CC, Chen, KY, Liao, WH \& Huang, HC 2013, 'Enhancing high quality oil accumulation and carbon dioxide fixation by a mixed culture of Chlorella sp. and 
Saccharomyces cerevisiae', Journal of the Taiwan Institute of Chemical Engineers, vol. 44, no. 6, pp. 936-942.

Simpson, ZF 2018, 'Engineered yeast and microalgae mutualisms: synthetic ecology applied to species isolated from winery wastewater', Master thesis, Stellenbosch University.

Show, PL, Tang, MSY, Nagarajan, D, Ling, TC, Ooi, CW \& Chang, JS 2017, 'A holistic approach to managing microalgae for biofuel applications' International Journal of Molecular Sciences, vol. 18, no. 1, pp. 215.

Smoczynski, L, Kalinowski, S, Cretescu, I \& Smoczynski, M 2019, 'Study of sludge particles formed during coagulation of synthetic and municipal wastewater for increasing the sludge dewatering efficiency', Water, vol. 11, no. 1, pp. 101.

Stephens, IL, Ross, Z, King, JH, Mussgnug, JH, Kruse, O, Posten, C \& Hankamer, B 2010, 'An economic and technical evaluation of microalgal biofuels', Nature Biotechnology, vol. 28, no. 2, pp. 126-128.

Subramanian, RDJ \& Jayasingam, JGP 2017, 'The impact of using microalgae as biofertilizer in maize (Zea mays L.)', Waste and Biomass Valorization, vol. 10, pp. 1101-1110.

Takriff, MS, Zakaria, MZ, Sajab, MS \& Teow, YH 2016, 'Pretreatments anaerobic palm oil mill effluent (POME) for microalgae treatment', Indian Journal of Science and Technology, vol. 9, no. 21, pp. 1-8.

Tanikkul, P, Juntarakod, P \& Pisutpaisal, V 2019, 'Optimization of biohydrogen production of palm oil mill effluent by ozone pretreatment', International Journal of Hydrogen Energy, vol. 44, no. 11, pp. 5203-5211.

Ullah, K, Ahmad, M, Sofia, SVK, Lu, P, Harvey, A \& Sultana, $\mathrm{S}$ 2015, 'Assessing the potential of algal biomass opportunities for bioenergy industry: a review', Fuel, vol. 1439, pp. 414-423.

Umamaheswari, J \& Shanthakumar, S 2019, 'Phycoremediation of paddy-soaked wastewater by indigenous microalgae in open and closed culture system', Journal of Environment Management, vol. 1, no. 243, pp. 435-443.

Udaiyappan, AFM, Hasan, HA, Takriff, MS \& Sheikh Abdullah, SR 2017, 'A review of the potentials, challenges and current status of microalgae biomass applications in industrial wastewater treatment', Journal of Water Process Engineering, vol. 209, pp. 8-21.

Ummalyma, SB, Gnansounou, E, Sukumaran, RK, Sindhu, R, Pandey, A \& Sahoo, D 2017, 'Bioflocculation: an alternative strategy for harvesting of microalgae - an overview', Bioresource Technology, vol. 242, pp. 227-235.
Vassilev, SV \& Vassileva, CG 2016, 'Composition, properties and challenges of algae biomass for biofuel application: an overview', Fuel, vol. 181, pp. 1-33.

Vatsos, IN, Angelidis, P, Theodoridis, A \& Batzios, C 2015, 'Integrated aquaculture - an old concept with new applications in Greece', International Journal of Data Analysis Techniques and Strategies, vol. 7, no. 2, pp. 129. Vizcaíno, AJ, Rodiles, A, López, G, Sáez, MI, Herrera, M, Hachero, I \& Alarcón, FJ 2018, 'Growth performance, body composition, and digestive functionality of Senegalese sole (Solea senegalensis, Kaup, 1858) juveniles fed diets including microalgae freeze-dried biomass', Fish Physiology and Biochemistry, vol. 44, no. 2, pp. 661-677. Vu, MTT, Jepsen, PM, Jorgensen, NOG, Hansen, BW \& Nielsen, SL 2019, 'Testing the yield of a pilot scale bubble column photobioreactor for cultivation of the microalga Rhodomonas salina as feed for intensive calanoid copepod cultures', Aquaculture Research, vol. 50, no. 1, pp. 63-71.

Walls, LE, Velasquez-Orta, SB, Romero-Frasca, E 2019, 'Nonsterile heterotrophic cultivation of native wastewater yeast and microalgae for integrated municipal wastewater treatment and bioethanol production', Biochemical Engineering Journal, vol. 151, pp. 107319.

Wang, M, Yang, Y, Chen, Z 2016a, 'Removal of nutrients from undiluted anaerobically treated piggery wastewater by improved microalgae', Bioresource Technology, vol. 222, pp. 130-138.

Wang, M, Cao, W, Wu, Y, Lu, H \& Li, B 2016b, 'Electrochemical oxidation of the poultry manure anaerobic digested effluents for enhancing pollutants removal by Chlorella vulgaris', Environmental Technology, vol. 37, no. 12, pp. 1451-1460.

Wang, Y, Xiao, Q, Liu, J, Yan, H \& Wei, Y 2015, 'Pilot-scale study of sludge pretreatment by microwave and sludge reduction based on lysis-cryptic growth', Bioresource Technology, vol. 190, pp. 140-147.

Wang, Y, Wei, Y \& Liu, J 2009, 'Effect of $\mathrm{H}_{2} \mathrm{O} 2$ dosing strategy on sludge pretreatment by microwave- $\mathrm{H}_{2} \mathrm{O} 2$ advanced oxidation process', Journal of Hazardous Materials, vol. 169, no. 1-3, pp. 680-684.

Wang, Z, Liu, Z, Noor, RS, Cheng, Q, Chu, X, Qu, B, Zhen, F \& Sun, Y 2019, 'Furfural wastewater pretreatment of corn stalk for whole slurry anaerobic co-digestion to improve methane production', Science of the Total Environment, vol. 674, pp. 49-57.

Wei, W, Wang, Q, Zhang, L, Laloo, A, Duan, H, Batstone, DJ \& Yuan, Z 2018, 'Free nitrous acid pre-treatment of waste 
activated sludge enhances volatile solids destruction and improves sludge dewaterability in continuous anaerobic digestion', Water Research, vol. 130, pp. 13-19.

Wrede, D, Taha, M, Miranda, AF, Kadali, K, Stevenson, T, Ball, AS \& Mouradov, A 2014, 'Co-cultivation of fungal and microalgal cells as an efficient system for harvesting microalgal cells, lipid production and wastewater treatment', PLoS ONE, vol. 9, no. 11, pp. 0113497.

Wu, YH, Hu, HY, Yu, Y, Zhang, TY, Zhu, SF, Zhuang, LL \& Lu, Y 2014, 'Microalgal species for sustainable biomass/lipid production using wastewater as resource: a review', Renewable and Sustainable Energy Reviews, vol. 33, pp. $675-688$.

Wu, X, Ruan, R, Du, Z \& Liu, Y 2012, 'Current status and prospects of biodiesel production from microalgae', Energies, vol. 5, no. 8, pp. 2667-2682.

Wu, Z \& Shi, X 2007, 'Optimization for high-density cultivation of heterotrophic Chlorella based on a hybrid neural network model', Letter Applied Microbiology, vol. 44 , pp. 13-18.

Xiao, K, Chen, Y \& Jiang, X 2017, 'Variations in physical, chemical and biological properties in relation to sludge dewaterability under Fe (II) - oxone conditioning', Water Research, vol. 109, pp. 13-23.

Xiao, B, Han, Y \& Liu, J 2010, 'Evaluation of biohydrogen production from glucose and protein at neutral initial $\mathrm{pH}$, International Journal of Hydrogen Energy, vol. 35, no. 12, pp. 6152-6160.

Xin, L, Hong-ying, H \& Jia, Y 2010, 'Lipid accumulation and nutrient removal properties of a newly isolated freshwater microalga, Scenedesmus sp. LX1, growing in secondary effluent', New Biotechnology, vol. 27, no. 1, pp. 59-63.

Xiong, J, Hassan, M, Wang, W \& Ding, W 2020, 'Methane enhancement by the co-digestion of soybean straw and farm wastewater under different thermo-chemical pretreatments', Renewable Energy, vol. 145, pp. 116-123.

Xu, Q, Wang, Q, Zhang, W, Yang, P, Du, Y \& Wang, D 2013, 'Highly effective enhancement of waste activated sludge dewaterability by altering proteins properties using methanol solution coupled with inorganic coagulants', Water Research, vol. 138, pp. 181-191.

Yaakob, Z, Ali, E, Zainal, A \& Takriff, MS 2014, 'An overview: biomolecules from microalgae for animal feed and aquaculture', Journal of Biological Research, vol. 21, no. 1, pp. 1-10.

Yen, HW, Chen, PW \& Chen, LJ 2015, 'The synergistic effects for the co-cultivation of oleaginous yeast-Rhodotorula glutinis and microalgae-Scenedesmus obliquus on the biomass and total lipids accumulation', Bioresource Technology, vol. 184, pp. 148-152.

Yang, B 2018, 'Electrochemical oxidation treatment of wastewater using activated carbon electrode', International Journal of Electrochemical Science, vol. 13, pp. 1096-1104. Younis, EM, Al-quffail, AS, Al-asgah, NA, Abdel-warith, AA \& Al-hafedh, YS 2018, 'Effect of dietary fish meal replacement by red algae, Gracilaria arcuata, on growth performance and body composition of Nile tilapia Oreochromis niloticus', Saudi Journal of Biological Sciences, vol. 25, no. 2, pp. 198-203.

Yu, X, Chen, L \& Zhang, W 2015, 'Chemicals to enhance microalgal growth and accumulation of high-value bioproducts', Frontiers in Microbiology, vol. 6, pp. 56.

Zhang, J, Li, N, Dai, X, Tao, W, Jenkinson, IR \& Li, Z 2018, 'Enhanced dewaterability of sludge during anaerobic digestion with thermal hydrolysis pretreatment: New insights through structure evolution', Water Research, vol. 131, pp. 177-185.

Zhang, Y, Su, H, Zhong, Y, Zhang, C, Shen, Z, Sang, W, Yan, G \& Zhou, X 2012, 'The effect of bacterial contamination on the heterotrophic cultivation of Chlorella pyrenoidosa in wastewater from the production of soybean products', Water Res., vol. 46, no. 17, pp. 5509-5516.

Zheng, Y, Qiu, S, Deng, F, Zhu, Y, Li, G \& Ma F 2019, 'Threedimensional electro-Fenton system with iron foam as particle electrode for folic acid wastewater pretreatment', Separation and Purification Technology, vol. 224, pp. 463474 .

Zhou, K, Zhang, Y \& Jia, X 2018, 'Co-cultivation of fungalmicroalgal strains in biogas slurry and biogas purification under different initial $\mathrm{CO} 2$ concentrations', Scientific Reports, vol. 8, no. 1, pp. 1-12. 